Western University

Scholarship@Western

Department of English Publications

English Department

Summer 6-2005

\title{
In Pursuit of Feminist Postfeminism and the Blessings of Buttercup
}

Teresa Hubel

Huron University College, Canada, tdhubel@huron.uwo.ca

Follow this and additional works at: https://ir.lib.uwo.ca/englishpub

Part of the English Language and Literature Commons, and the Women's Studies Commons

Citation of this paper:

Hubel, Teresa, "In Pursuit of Feminist Postfeminism and the Blessings of Buttercup" (2005). Department of English Publications. 127.

https://ir.lib.uwo.ca/englishpub/127 


\title{
In Pursuit of Feminist Postfeminism and the Blessings of Buttercup
}

\author{
Teresa Hubel \\ Huron University College
}

\begin{abstract}
I inism" is often and perhaps most frequently used-by the mainstream media generally and by actual people-as a kind of casual dismissal of feminism that comes implicitly coupled with the suggestion that the cutting-edge place to be these days, with regard to women, is the one where the old victim mentality has been sloughed off and a new flying-free-ofthose-chains approach to gender in all its diversity and in all its equal opportunity has been boldly embraced. Given the terms of this unstated argument, any criticism of this postfeminism automatically slots the critic into the role of the relic, the leftover women's libber still fighting battles that no longer need to be fought. And who among us, standing in front of our students or our colleagues, wants to be seen to be so pathetically tilting at windmills? Only the bravest. Or the least self-conscious.

Because this form of postfeminism works to keep women quiet about their structural complaints and teaches them to interpret those complaints as being of individual rather than collective origin, it works as another new face of patriarchy. To publicly and proudly claim feminism, then, is to do what our female feminist forerunners have done for us and for decades: it is to combat patriarchy. As Rudyard Kipling suggested in his famous
\end{abstract}

ESC 31.2-3 (June/September 2005): 17-21 
Teresa Hubel is an Associate Professor of English at Huron University College in London, Ontario. She has published various things-a book, an edited collection, numerous essays-on various topics, though she has tended to focus on the literature and history of colonial and postcolonial India. She continues to be grateful to feminism. patrilineal legacy to his son, it is an act of courage to "keep your head when all about you/ Are losing theirs and blaming it on you" (578).

I wish it were this simple. Raised in a world where individualist and masculine models like this one were valued, I've been conditioned to hunger after this role of the lone male hero fighting against great odds. I may have been born a female, but I want to die as Clint Eastwood or maybe Bruce Willis (or if not die at least ride off solitary and strong into the sunset). I tell my students to pay attention to this cross-culturally ubiquitous chosen-boy story, which has been reiterated so many times that it has become invisible as a narrative, some of its latest incarnations in the western world being found in the American film The Matrix and the English public-school adventures of Harry Potter. Strange how we never seem to get tired of certain stories and interpretations, while others, such as feminist understandings of the way the world works, are rendered tiresome after only a few renditions. Perhaps this has something to do with the fact, stunningly realized in the 1970 os as the result of studies into mixed-sex and same-sex conversations, that, from certain male-centred perspectives, any talk from women is too much talk. ${ }^{1}$

When I was a younger feminist, I used to think that all I needed to do to free myself of patriarchal dictates was to stay vigilant and be aware of how such dictates were delivered, through which narratives, codes of normality, sets of values. Now I'm not as confident about any individual's capacity, including my own, to rescue herself from entrenched systems of oppression, and I'm far more respectful of their tenacity. So I'm prepared to forgive myself for lapsing into such a weirdly hybrid fantasy as this one about being a lone feminist yet still masculine hero. And, by the same token, I try to be patient when my students, particularly the women, make it clear that feminism is something they no longer need, given that the war's over and we've won, and now we're entering this new triumphant

1 In their essay, "Small Insults: A Study of Interruptions in Cross-Sex Conversations between Unacquainted Persons," Candace West and Don H. Zimmerman point out that, contrary to common wisdom, men actually talk more than women in cross-sex conversations and, further, that they interrupt women more than women interrupt them. Dale Spender interprets this finding by observing, in Man Made Language, that the stereotype of the talkative woman arises from the unexamined assumption that the appropriate role for women is that of the silent listener: "The talkativeness of women has been gauged in comparison not with men but with silence. Women have not been judged on the grounds of whether they talk more than men, but of whether they talk more than silent women. When silence is the desired state for women ... then any talk in which a woman engages can be too much" (42).

$18 \mid$ Hubel 
stage of human history called postfeminism. I try not to be irritated or angry. Though I am. Often.

I have a secret identity. It's Buttercup from the Power Puff Girls, the one with blazing green eyes whose image stares out at me from the coffee cup I'm holding as I write this. Her perpetual anger occasionally makes her misuse her power, smashing buildings and such instead of pursuing niceness and trouncing evil.

But, as I've said, fighting patriarchy is not really this simple. For not only is the lone feminist hero inadequate to the task of annihilating this decidedly unvenerable institution of male domination, postfeminist or otherwise, but postfeminism isn't even consistently patriarchal. Outside of the mainstream media and the mouths of many undergraduate students, postfeminism is also feminist. It's a derivative of feminism that, as its name stipulates, does indeed stand against previous feminisms, specifically the liberal and maternal/radical positions that dominated baby-boomer (meaning second-wave, middle-class, mostly white) feminism, positions that respectively sought equal rights within the established bastions of authority (capitalism, liberal democracy, heterosexual marriage, etc.) or the valorization of the female over the male, the feminine over the masculine. What both of these feminist positions have in common, other than the fact that they each have engendered enormous social change in a relatively short period of time and though they disagree over so very much, is that they assume a biological connection between that group of people all contemporary human societies designate female. Postfeminism seriously questions this so-called natural bond between women, pointing out that this too is a patriarchal presumption and that more differences-class differences, cultural ones, racial frontier lines-separate the groups the world calls women than bind us to one another.

So the "post" part of the word is like the "post" in "postcolonial"; it means not only that its borders are nebulous and its disciplinary concerns multifarious but also that it's a reaction to as well as a step further in a theoretical and activist movement. Far from proclaiming the death of patriarchy, this feminist postfeminism vigorously suggests that the old liberal and maternal tools can't work to vanquish the enemy. New tools, fashioned from postcolonial, poststructuralist, and queer theories, are needed to combat such a virulent shape-shifter. Among these tools is a great unknowingness about where such a fundamental critique of patriarchy will take us, but it's definitely not to the safe liberal future of equal opportunity for men and women or to a radical matriarchal utopia. Among them too is the understanding that the sands shift where we stand when 


\section{The problem}

\section{with this evalu-}

\section{ation of the}

situation is that

it presumes the

radical efficacy

of individual

agency, ... we critique, that we are insecure in our questioning and so thoroughly implicated in the systems we hope to topple.

It has its limitations, this postfeminism: in its rejection of identity politics and its reach for a genderless or many-splendoured gendered reality, one that can be brought into being most famously through such potentially destabilizing performative acts as drag, it sometimes is itself unconscious of the differences that divide us, assuming that we are all comfortably enough ensconced in a middle-class, white, western place with middle-class, white, western choices and compulsions and commitments and obligations. But is the way out of gender categories a matter of performing one's gender in such a manner as to confound recognized categories? The problem with this evaluation of the situation is that it presumes the radical efficacy of individual agency, in other words, that individuals, as my passionate/compassionate undergraduate students often yearningly assert, really can change themselves and the world, like Gandhi, virtually single-handedly (or so this particular chosen-boy story goes). And it assumes that individuals have both the ability and the inclination to enact this staged, self-conscious gender fluidity. Other political realities and responsibilities, obvious ones being those that arise from class and race experiences, can intrude on a person's capacity for performative action or her willingness to participate in it. For instance, the obligations of solidarity in the face of deep-rooted oppression can make a luxury out of the required performative conditions, a luxury that is neither easy to acquire nor even necessarily desirable.

This postfeminism, like its feminist predecessor, isn't always humble about what it doesn't know or cannot know. It doesn't always shut up so that others can speak.

I'm going to sound unreasonable when I say I'm heartened by it and intrigued by the astonishing mysterious future it stretches to grasp. That it will alter things, I've no doubt. I'm convinced too that we mustn't ever let it rest easy in its assumptions and its proclamations. We mustn't let ourselves rest easy either. Not in our allegiances with one another, which must be forged reiteratively rather than taken for granted. Not in our personal capacities as bringers of change. Or in our understanding about what it means to be female. My friend Cathy Benford has suggested to me that conservative forces are winning the public media battle against feminists. By demonizing us as well as exaggerating the gains of feminism, they make it seem a logical impossibility to discriminate against women, a situation she deplores and about which she is anxious, eloquently concluding, "But I can't seem to shake the feeling that it still not safe to be a girl in the world.

20 | Hubel 
I mean that in the physical sense and the economic sense" ("Re: note to fellow garden goddess").

At the risk of sounding like I can't make up my mind or construct a coherent argument, I think she's right. And I'm scared too. If girls aren't safe in our world, and clearly they aren't, Buttercup's rage, her renunciation of niceness, makes sense.

\section{Works Cited}

Benford, Catherine. "Re: note to fellow garden goddess." E-mail to the author. 21 May 2005.

Kipling, Rudyard. "If." Complete Verse, Definitive Edition. New York: Anchor Doubleday, 1989.

Spender, Dale. Man Made Language. London: Routledge and Kegan Paul, 1980.

West, Candace, and Don H. Zimmerman. "Small Insults: A Study of Interruptions in Cross-Sex Conversations between Unacquainted Persons." Language, Gender, and Society. Eds. Barrie Thorne, Cheris Kramarae, Nancy Henley. Boston: Heinle and Heinle, 1983. 103-17. 